\title{
Proteomic Profiling of Human Small Cell Lung Cancer Cell Line NCI-H211
}

Hee Young Cho, M.S., Mi Kyung Kim, B.S., Young Do Yoo, Ph.D. ${ }^{1}$, Myung Ju Ahn, M.D. ${ }^{2}$ and Joung Soon Jang, M.D.

Department of Internal Medicine, GyeongSang National University College of Medicine and GyeongSang Institute of Health Sciences, Jinju; ${ }^{1}$ Genomic Research Center for Lung and Breast/Ovarian Cancers, Korea University College of Medicine, Seoul; ${ }^{2}$ Department of Internal Medicine, Hanyang University College of Medicine, Seoul, Korea

Purpose: Small cell lung cancer is one of the major causes of death from cancer worldwide. To explore the expressions of global protein in small cell lung cancer cells, a proteomic approach, to identify the proteins, was used and the establishment of a protein reference map attempted.

Materials and Methods: Two-dimensional gel electrophoresis (2-DE), with subsequent analysis by mass spectrometry (MS), was applied to the study of protein identification from a small cell lung cancer cell line, NCIH211. The cells were lysed, and the extracts subjectedto isoelectric focusing, with immobilized $\mathrm{pH}$ gradients, followed by second dimension SDS-PAGE. The polypeptides were identified by peptide mass fingerprinting, with MALDI-TOF MS, after in-gel protein digestion.

Results: From silver staining of the gel, around two

\section{서 론}

프로티움 연구(proteomics)는 2차원 전기영동(Two-dimensional gel electrophoresis), mass spectrometry 및 생물정보학 (bioinformatics)을 근간으로 하여 단백질을 총체적으로 분석 하는 연구방법으로 기존의 유전체 연구 결과를 보완하는 유용한 연구기법이다(1). 최근에 프로티움 연구기법의 발전 에 의하여 인간 종양세포에서의 단백질발현 양상이 빠르게 밝혀지고 있어 방광암, 간암, 위암, 유방암 등의 인체 종양 조직 및 세포주에의 분석에 응용되어 연구범위를 넓혀가고

Correspondence: Joung Soon Jang, Division of Hematology- Oncology, Department of Internal Medicine, GyeongSang National University Hospital, 90 Chiram-dong, Jinju 660-702, Korea. (Tel) 055-750-8054, (Fax) 055-758-9122, (E-mail) jsjang@ nongae.gsnu. ac.kr

Received October 13, 2003, Accepted December 17, 2003

This work was supported by grant No. R01-2001-000-00151-0 from the Basic Research Program of the Korea Science \& Engineering Foundation. thousands protein spots were separated by the 2-DE. Of these protein spots visualized in the gel, one hundred and ten were identified by peptide mass fingerprinting. Different proteins, such as enzymes, cytoskeletal proteins and proteins common to eukaryotic cells, were identified.

Conclusion: The protein expressions of the small cell lung cancer cells were analyzed to establish a protein reference map. The reference map presented here may serve as a working tool for the further study of small cell lung cancer. (Cancer Research and Treatment 2003;35:489 -496)

Key Words: Proteome, Small cell lung cancer, Reference map

있으며 이를 이용한 종양 표식자 등의 진단 법 및 목적 단 백질 발굴을 통한 치료제 개발이 진행되고 있으나 최근 국 내에서 발생률이 증가하고 있는 폐암에 대해서는 높아지는 사회적인 손실에도 불구하고 아직 진단 및 치료법 개발에 획기적 진전이 없는 상태이다. 특히 소세포 폐암은 선암이 나 편평상피세포암 들에 비하여 진행이 빠르고 조기에 전 이를 일으켜 예후가 좀더 불량하다 $(2 \sim 6)$. 최근 분자 생물 학의 발전에 의하여 폐암의 병태 생리의 연구에 대한 많은 발전이 있었으나 전반적으로 단백질 발현을 조망하는 연구 는 활성화되지 못하였다. 본 연구에서는 소세포 폐암 세포 주에서의 단백질 발현 양상을 mass spectrometry를 기반으로 한 peptide mass fingerprinting에 의하여 단백질 동정을 하여 구명하고 이를 표준 단백질 지도로 삼아 향후 종양 표식자 개발 및 암 백신 개발 등의 치료제 개발의 기반 연구로 삼 고자 하였다. 


\section{대상 및 방법}

\section{1) 대상}

연구에 사용된 폐암 세포주(NCI-H211, 전이성 소세포 폐 암 유래)는 ATCC (Rockvill, MD)에서 구하였으며 암 세포 는 $10 \%$ 태아 우혈청 및 $1 \%$ penicillin/amphotericin 복합 항균 /항진균제가 함유된 RPMI- 1640 배지에서 $37^{\circ} \mathrm{C} 5 \% \mathrm{CO}^{2}$ 에서 3 4일 마다 계대 배양하였으며 70\% confluent 상태에서 수 집하여 즉시 분석하였다. 프로티움 분석에 사용한 Ampholyte, immobilized pH gradients (IPG) strip은 Amersham Co. (Cleveland, $\mathrm{OH}$ ), protease cocktail, urea, CHAPS는 Sigma Co. (St. Louis, MO)에서 구하여 사용하였다.

\section{2) 세포성분 분리 및 프로티움 분석 시료 전(前) 처리}

수집된 암 세포에 lysis buffer (8 M urea, 4\% CHAPS, 40 $\mathrm{mM}$ Tris, $100 \mathrm{mM}$ DTT, $2 \%$ Ampholyte)와 protease inhibitor (1mM EDTA (pH 8.0), protease cocktail)를 넣어 녹인 다음 실온에서 1 시간 반응시킨 후 원심분리 $\left(4^{\circ} \mathrm{C}, 15,000 \mathrm{rpm}, 10\right.$ 분)하여 상등 액을 취하여 Bradford 방법으로 단백질을 정 량 후 $-70^{\circ} \mathrm{C}$ 에 보관하였다가 사용하였다.

\section{3) 이차원 전기영동(Two-dimensional gel electrophore-} sis; 2-DE)

일차원 전기영동인 isoelectric focusing (IEF)은 immobilized $\mathrm{pH}$ gradients (linear $\mathrm{pH}$ gradient 4-7, $17 \mathrm{~cm}$ ) strip으로 Protean IEF cell (Bio-Rad, Hercules, CA)을 사용하여 수행하 였다. Gel은 focusing tray (Bio-Rad)에 in-gel loading 방식으 로 시료 $(100 \mu \mathrm{g})$ 와 같이 rehydration solution (7 M urea, $2 \mathrm{M}$ Thiourea, 2\% CHAPS, $100 \mathrm{mM}$ DTT, 0.5\% Ampholyte, Bromophenol Blue 소량)을 넣은 다음 12 14시간 정도 rehydration과정을 거친 후에 $250 \mathrm{~V}$ 에서 15 분, $10,000 \mathrm{~V}$ 로 3 시 간, 최종 $40,000 \mathrm{vhr}$ 까지 전압을 올려주었다. 일차원 전기영 동 후 Equilibration buffer I (6 M urea, $50 \mathrm{mM}$ Tris- $\mathrm{HCl} \mathrm{pH}$ 8.8, 30\% glycerol, 2\% SDS, 소량의 Bromophenol Blue, 10 $\mathrm{mM} \mathrm{DTT}$ )을 실온에서 10 분간 반응시킨 후 이 조성에 $2.5 \%$ iodoacetamide를 첨가한 Equilibration buffer II에서 다시 10분 간 실온에서 반응시킨 후 용액을 제거하였다. 이차원 전기 영동은 PROTEAN II xi Cell (Bio-Rad) 전기영동기에 7.5 $17.5 \%$ SDS-polyacrylamide gradient gel $(20 \times 20 \mathrm{~m})$ 을 만들어 equibilibartion이 끝난 strip을 $10^{\circ} \mathrm{C}$ 에서 $5 \mathrm{~mA} / \mathrm{gel}$ 로 1시간 전 기 영동 후 $10 \mathrm{~mA} / \mathrm{gel}$ 로 15 시간 정도 수행하였다.

\section{4) Image analysis}

전기영동이 끝난 gel은 은 염색과 Coomassie blue염색을 하였다. 은 염색을 위하여 SDS-PAGE가 끝난 gel을 methanol: acetic acid: water $(50: 10: 38)$ 용액에 1.5 시간 적시고 $50 \%$ ethanol로 20 분간 2 회 세척 후 $0.02 \% \mathrm{Na}_{2} \mathrm{~S}_{2} \mathrm{O}_{3}$ 용액에 1 분간 전처치하였다. 단백질은 $0.2 \% \mathrm{AgNO}_{3}, 0.075 \% \mathrm{v} / \mathrm{v}$ formalin 용액에 20 분간 염색하여 수세하고 $0.06 \% \mathrm{v} / \mathrm{v}$ formalin, $2 \% \mathrm{Na}_{2} \mathrm{CO}_{3}, 0.0004 \% \mathrm{Na}_{2} \mathrm{~S}_{2} \mathrm{O}_{3}$ 가 함유된 용액에서 발 색시켰다. Coomassie blue염색은 $2 \%$ phosphoric acid가 함유 된 $30 \%$ ethanol용액에 20분간 3회 고정하고 $2 \%$ phosphoric acid로 세척한 후 $18 \%$ ethanol, $2 \%$ phosphoric acid, $15 \%$ ammonium sulfate 함유 용액에 30 분간 반응시킨 다음 Coomassie Brilliant Blue G-250을 1\%의 농도가 되게 가하여 밤새 염색하였다. 이런 과정을 거쳐 발색된 단백질 패턴은 고해상도 스캐너(GS-710 Calibrated imaging Densitometer, $\mathrm{Bio}-\mathrm{Rad})$ 로 스캐닝하여 저장하여 gel 이미지 분석을 하였다.

\section{5) In-gel digestion}

Gel에 Coomassie blue염색을 한 후 목표로 하는 단백질 스폿을 gel에서 잘라내어 증류수로 수세 후 50\% acetonitrile 로 15분씩 2회 세척하였다. 용액을 제거한 후 다시 $100 \%$ acetonitrile용액에 5분간 두었다가 용액을 제거하고 $0.1 \mathrm{M}$ $\mathrm{NH}_{4} \mathrm{CO}_{3}$ 용액에 5 분간 넣어 재함수시킨 후 동일 부피의 $100 \%$ acetonitrile을 첨가하여 15 분간 반응시킨 후 용액을 완 전히 제거한 후 vacuum centrifuge를 이용하여 gel을 완전히 건조시켰다.

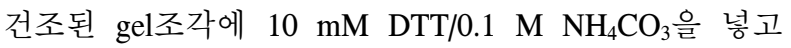
$56^{\circ} \mathrm{C}$ 에서 45 분간 반응시킨 후 실온에서 $55 \mathrm{mM}$ iodoacetamide/ $0.1 \mathrm{NH}_{4} \mathrm{CO}_{3}$ 을 넣고 어두운 곳에서 30 분간 반응시킨 후 용액을 제거하였다. $\mathrm{Gel}$ 을 $0.1 \mathrm{M} \mathrm{NH}_{4} \mathrm{CO}_{3}$ 용액에서 5 분간 세척 후 같은 부피의 $100 \%$ acetonitile을 넣고 15 분간 두었다 가 용액을 제거하였으며 이 과정을 2회 반복하였다. Gel을 수세 후 Vaccum centrifuge로 완전히 건조시키고 digestion buffer (50 mM NH $\mathrm{CO}_{3}, 5 \mathrm{mM} \mathrm{CaCl}, 12.5 \mathrm{ng} / \mu \mathrm{l}$ trypsin)를 넣고 45 분간 얼음 속에서 반응시킨 후 용액을 제거하고 다 시 trypsin이 제거된 digestion buffer를 넣고 $37^{\circ} \mathrm{C}$ 에서 $16 \sim 20$ 시간 동안 반응시켜 단백질을 가수 분해시켰다. 그 다음 25 $\mathrm{mM} \mathrm{NH} \mathrm{CO}_{3}$ 가 포함된 $50 \%$ acetonierile을 넣고 30 분간 두었 다가 5\% formic acid/acetonitrile (1:1 volume)을 넣고 30분 간 두기를 2 회 반복해 펩타이드를 추출하였고 펩타이드 추 출용액은 vacuum centrifuge로 완전히 건조하였다. 
6) Matrix-assisted laser desorption ionization time-offlight (MALDI-TOF) mass spectrometry 분석에 의 한 단백질 동정

Trypsin분해에 의하여 얻어진 각 펩타이드는 water, acetonitrilematrix 및 trifluoroacetic acid (93:5:2 volume)의 용액 에 용해 후 'solution phase nirocellulose법'에 의하여 처리하 였다. a-cyano-4-hydroxycinnamic acid $(40 \mathrm{mg} / \mathrm{ml})$ 와 nitrocellulose $(20 \mathrm{mg} / \mathrm{ml})$ 용액 및 2-propanol을 $2: 1:$ 1로 섞은 후 peptide calibrant로 des-Arg-bradykinin (monoisotopic mass, 904.4681)과 neurotensin (1672.9715)을 첨가한 후 잘 혼합하 여 분석용 플레이트에 올려 건조한 후 $5 \%$ formic acid와 Milli-Q water로 세척하고 MALDI-TOF mass spectrometry (Voyager-DE STR, PerSeptive Biosystems, Framingham, MA) 에 의하여 질량 값을 분석하였다. 이렇게 얻어진 질량 값은 보정 후 MS-FIT (http://prospector.ucsf.edu/ucsfhtml4.0/msfit. $\mathrm{htm}$ )와 ProFound (http://129.85.19.192/profound_bin/WebProFound.exe)에서의 탐색 도구를 이용하여 SWISS-PROT이나 $\mathrm{NCBI}$ 데이터베이스를 이용하여 peptide mass fingerprinting 법에 의하여 단백질을 동정하였다.

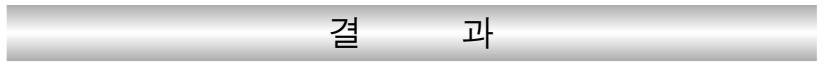

1) 폐암 세포주 NCI-H211에서의 2-DE 이미지

은 염색에서 약 2000 개의 단백질이 분리되었다(data not shown). 은 염색 이미지에서 목표로 하는 단백질 스폿을 선 발한 후 In gel digestion을 위하여 Coomassie blue염색을 하 였다. Fig. 1은 Coomassie blue염색을 한 전형적인 2-DE 이미 지로서 고유번호가 표시된 스폿은 MALDI-TOF mass spectrometry 분석에 의하여 단백질이 동정되었다.

\section{2) 단백질 동정}

MALDI-TOF mass spectrometry 분석 및 database탐색을 통하여 110 종의 단백질이 동정되었으며 Table 1 에 정리되 어 있다. MALDI-TOF mass spectrum 중의 대표적인 예는 Fig. 2에 나타나 있다.

\section{고 찰}

프로티움(proteome)이라는 용어는 protein과 genome을 합

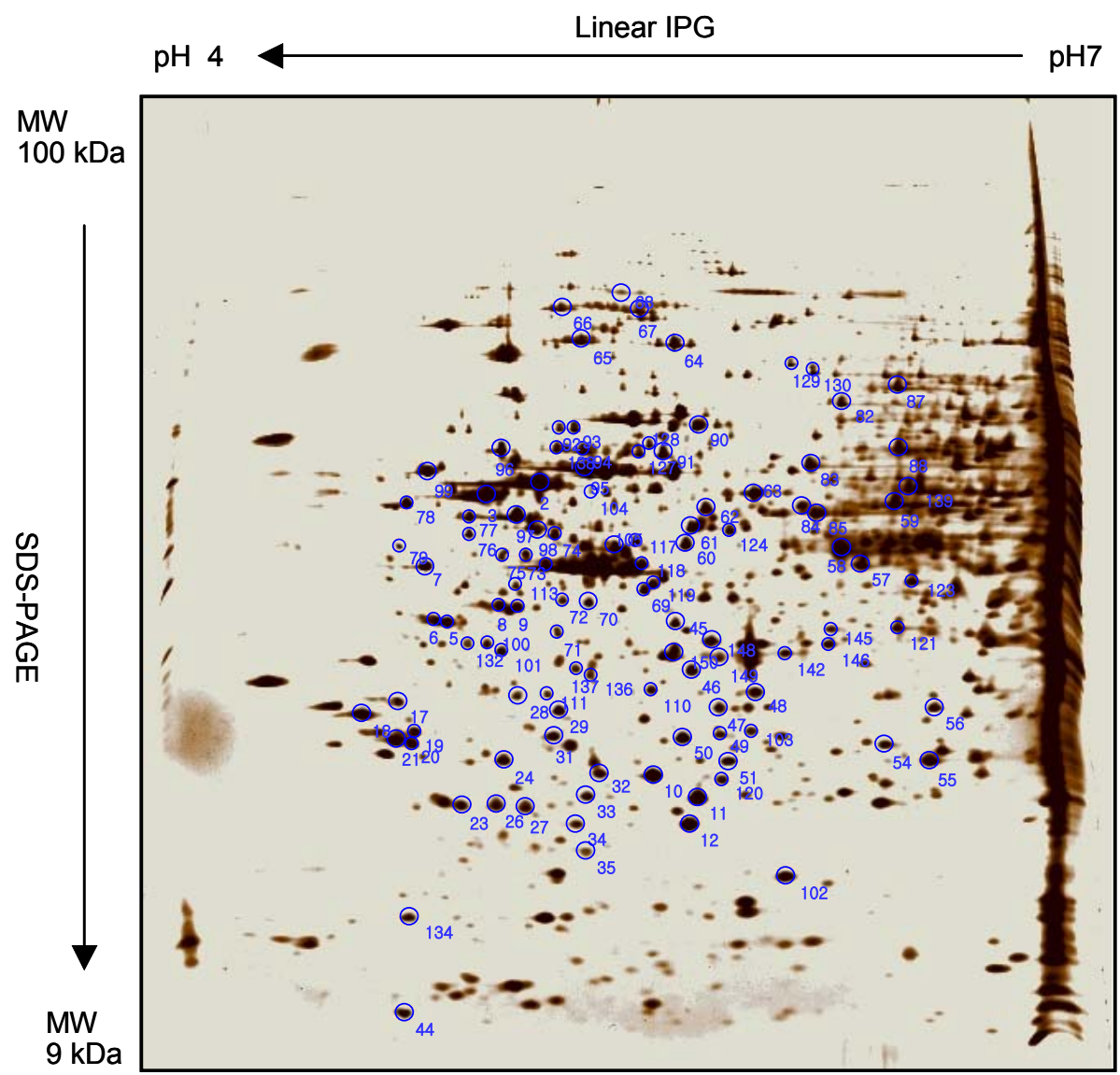

Fig. 1. 2-DE map of small cell lung cancer cell line NCIH211. 
A

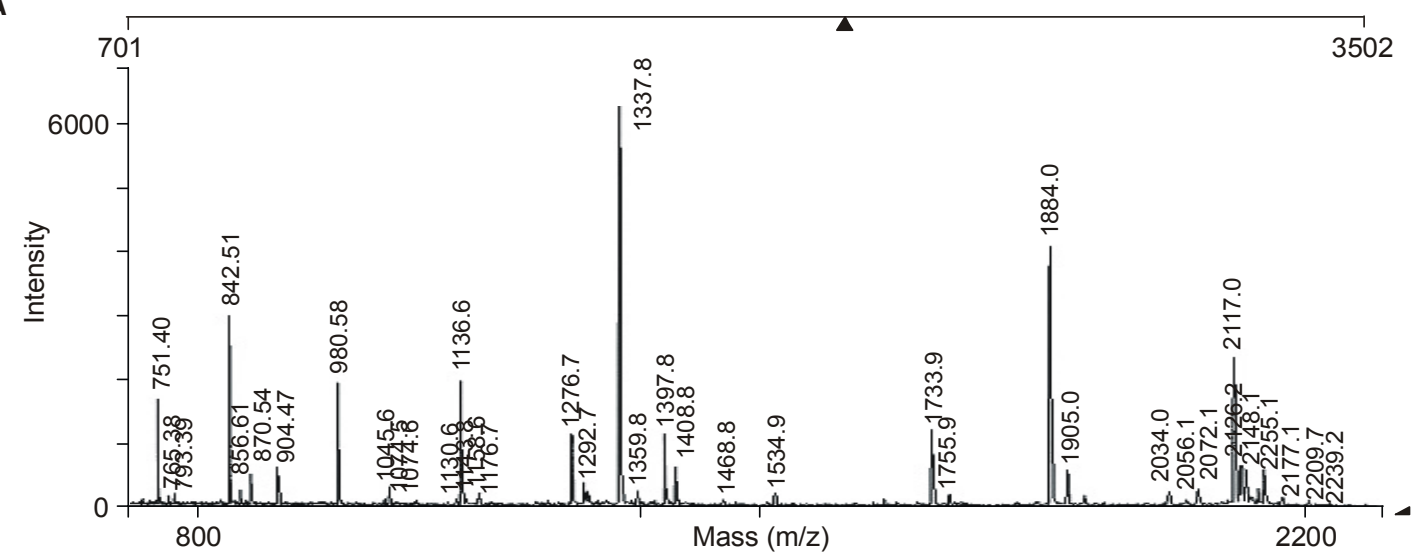

B

10/40 matches (25\%)

Acc. \#: P09211 Species: HUMAN Name: Glutathione S-transferase P (GST class-pi) (GSTP1-1) Index: 17933 MW: 23356 Da pl: 5.4

\begin{tabular}{|c|c|c|c|c|c|c|c|}
\hline $\begin{array}{l}\mathrm{m} / \mathrm{z} \\
\text { submitted }\end{array}$ & $\begin{array}{l}\mathrm{MH}+ \\
\text { matched }\end{array}$ & $\begin{array}{l}\text { Delta } \\
\text { ppm }\end{array}$ & Modifications & Start & End & $\begin{array}{l}\text { Missed } \\
\text { cleavages }\end{array}$ & $\begin{array}{l}\text { Database } \\
\text { sequence }\end{array}$ \\
\hline 751.3991 & 751.4354 & -48 & & 76 & 82 & 0 & (R) TLGLYGK (D) \\
\hline 1136.6156 & 1136.5774 & 34 & & 46 & 55 & 0 & (K) ASCLYGQLPK (F) \\
\hline 1292.6655 & 1292.6309 & 27 & 1Met-ox & 20 & 30 & 0 & (R) MLLADQGQSWK (E) \\
\hline 1468.7789 & 1468.7663 & 8.6 & & 1 & 12 & 0 & (-) MPPYTVVYFPVR (G) \\
\hline 1733.9087 & 1733.8598 & 28 & & 31 & 45 & 0 & (K) EEVVTVETWQEGSLK (A) \\
\hline 1883.9620 & 1883.9503 & 6.2 & & 56 & 71 & 0 & (K) FQDGDLTLYQSNTILR (H) \\
\hline 2117.0371 & 2116.9821 & 26 & & 83 & 101 & 0 & (K) DQQEAALVDMVNDGVEDLR (C) \\
\hline 2126.1724 & 2126.1610 & 5.4 & & 122 & 141 & 0 & (K) ALPGQLKPFETLLSQNQGGK (T) \\
\hline 2132.9964 & 2132.9770 & 9.1 & 1Met-ox & 83 & 101 & 0 & (K) DQQEAALVDMVNDGVEDLR (C) \\
\hline 2155.0866 & 2155.0599 & 12 & & 104 & 121 & 1 & (K) YISLIYTNYEAGKDDYVK \\
\hline
\end{tabular}

Fig. 2. (A) Peptide mass fingerprinting of protein spot 11 in 2-DE map. (B) Matching of protein spot 11 peptide mass fingerprint data (SWISS PROT No. p 09211).

성하여 만들어진 용어로 어떤 세포나 조직에서 발현되는 단백질의 총체를 뜻하며 프로티움 분석연구는 기능적 유전 체 연구와 생물정보학 연구와 결합하여 기존의 유전체 연 구를 상호 보완하는 방법으로 기존의 완성된 유전체 연구 를 보완 발전시켜 실제에 이용할 수 있게 하는 postgenome 영역에 중요한 연구방법이다. 프로티움 연구의 스케일 면 에서의 단백질 분석의 방향은 현재 사용되는 단백질의 전 사 후 수식화(posttranslational modification)를 포함한 단백질 발현의 검색 및 분리 동정, 단백질 활성 검색, 복합체 내에 서의 단백질 상호반응 및 세포 내 단백질 국재화(localization) 등을 통한 단백질 기능 분석 등이다(7). 이러한 프 로티움 분석연구을 통한 전체적인 단백질의 성상 및 활성 연구를 통하여 암 등의 질병의 병리기전에 대한 이해를 넓 힐 수 있고 임상적으로는 신약개발이나 새로운 진단 표식 자를 개발하는 데 이용될 수 있다(8 10). 현재 사용되는 프 로티움 분석연구는 2차원 전기영동 및 이미지분석, mass spectrometry 및 단백질 분석 데이터베이스를 근간으로 하는
단백질 분석기술을 기초로 하여 여러 방향으로 응용이 되 고 있는데 복합체를 이루는 단백질을 polypeptide 성분으로 나누어 분리하여 분석하는 연구, 정상과 악성세포 혹은 세 포의 분화단계별 단백질 발현 패턴 등 각 시료에 따른 단백 질 발현 경향을 비교 분석하거나 세포에 약제 등을 처리하 는 조건을 만들어 이에 대한 세포의 반응을 단백질 발현을 통하여 연구하는 것이다.

이러한 연구를 통해 얻은 자료는 유전체 정보와의 관계 데이터베이스를 구축하기도 하는데 표준 gel format을 사용 하여 이차원 전기영동으로 분리한 단백질 스폿을 단백질미 량분석기술과 접목하여 gel상에 나타난 모든 단백질을 게 놈정보의 특정 유전자와 연결시켜 유전자-단백질(유전자산 물)의 대응관계를 데이터베이스로 구축하여 활용할 수 있 다(11). 이러한 연구의 일환으로 편평상피세포 폐암 환자의 조직에서 단백질을 동정하여 프로티움 데이터베이스를 구 축한 후 향후 연구를 위한 molecular marker를 스크리닝하고 자 하는 연구가 있고 소세포 폐암을 비롯한 여러 종류의 
Table 1. Proteins identified in small-cell lung cancer cell line NCI-H211

\begin{tabular}{|c|c|c|c|c|c|}
\hline $\begin{array}{l}\text { Spot } \\
\text { No. }\end{array}$ & Protein name & $\begin{array}{c}\text { Accession } \\
\text { No. }\end{array}$ & $\begin{array}{l}\text { Masses } \\
\text { matach }\end{array}$ & $\begin{array}{c}\text { Mw } \\
(\mathrm{kDa}) / \mathrm{pI}\end{array}$ & $\begin{array}{c}\text { Seq. } \\
\text { coverage }\end{array}$ \\
\hline 2 & Alpha-tubulin & 37492 & $15(40)$ & $50,158 / 5.0$ & 36 \\
\hline 3 & Beta-tubulin & 2119276 & $12(52)$ & $48,880 / 4.7$ & 24 \\
\hline 4 & Actin, beta & 14250401 & $13(43)$ & $41,005 / 5.6$ & 39 \\
\hline 5 & Nucleolar phosphoprotein B23, numatrin & 16307090 & $5(26)$ & $29,465 / 4.5$ & 28 \\
\hline 6 & Nucleolar phosphoprotein B23, numatrin & 16307090 & $6(37)$ & $29,465 / 4.5$ & 28 \\
\hline 7 & Laminin-binding protein & 34234 & $11(35)$ & $31,794 / 4.8$ & 43 \\
\hline 8 & Heterogeneous nuclear ribonucleoproteins $\mathrm{C} 1 / \mathrm{C} 2$ & 13097279 & $18(50)$ & $32,338 / 4.9$ & 47 \\
\hline 9 & Heterogeneous nuclear ribonucleoproteins $\mathrm{C} 1 / \mathrm{C} 2$ & P07910 & $12(52)$ & $33,688 / 5.0$ & 32 \\
\hline 10 & Ubiquitin carboxyl-terminal hydrolase isozyme L1 & P09936 & $7(21)$ & $24,825 / 5.3$ & 30 \\
\hline 11 & Glutathione S-transferase $\mathrm{P}$ & P09211 & $10(25)$ & $23,356 / 5.4$ & 60 \\
\hline 12 & Peroxiredoxin 2 & P32119 & $8(16)$ & $21,892 / 5.7$ & 40 \\
\hline 17 & Tropomyosin alpha 3 chain & P06753 & $7(38)$ & $32,819 / 4.7$ & 20 \\
\hline 18 & 14-3-3 protein epsilon & $\mathrm{P} 42655$ & $16(50)$ & $29,174 / 4.6$ & 49 \\
\hline 19 & $14-3-3$ protein gamma & P35214 & $14(36)$ & $28,303 / 4.8$ & 45 \\
\hline 20 & 14-3-3 protein beta/alpha & P31946 & $5(21)$ & $28,083 / 4.8$ & 20 \\
\hline 21 & 14-3-3 protein zeta/delta & P29312 & $14(41)$ & $27,745 / 4.7$ & 44 \\
\hline 23 & Proteasome subunit beta type 6 precursor & P28072 & 6 (19) & $25,358 / 4.8$ & 25 \\
\hline 24 & Rho GDP-dissociation inhibitor 1 & P52565 & $7(21)$ & $23,207 / 5.0$ & 25 \\
\hline 26 & Lactoylglutathione lyase & Q04760 & $10(50)$ & $20,720 / 5.2$ & 38 \\
\hline 27 & Lactoylglutathione lyase & Q04760 & 11 (39) & $20,720 / 5.2$ & 51 \\
\hline 28 & Tubulin-specific chaperone $\mathrm{B}$ & Q99426 & 7 (36) & $27,326 / 5.1$ & 34 \\
\hline 29 & Chloride intracellular channel protein 1 & O00299 & $11(45)$ & $26,923 / 5.1$ & 53 \\
\hline 30 & Proteasome subunit alpha type 3 & $\mathrm{P} 25788$ & $12(40)$ & $28,433 / 5.2$ & 38 \\
\hline 32 & Ubiquitin carboxyl-terminal hydrolase isozyme L1 & P09936 & $5(21)$ & $24,825 / 5.3$ & 29 \\
\hline 33 & Ubiquitin-conjugating enzyme $\mathrm{E} 2-25 \mathrm{kDa}$ & P27924 & $8(28)$ & $22,407 / 5.3$ & 43 \\
\hline 34 & ATP synthase D chain, mitochondrial & O75947 & $7(30)$ & $18,491 / 5.2$ & 44 \\
\hline 44 & Small nuclear ribonucleoprotein $\mathrm{F}$ & Q15356 & $5(20)$ & $9,725 / 4.7$ & 31 \\
\hline 45 & Eukaryotic translation initiation factor 3 subunit 2 & Q13347 & $11(55)$ & $36,502 / 5.4$ & 36 \\
\hline 46 & Inorganic pyrophosphatase & Q15181 & $10(45)$ & $32,660 / 5.5$ & 37 \\
\hline 47 & F-actin capping protein beta subunit & P47756 & $12(54)$ & $31,351 / 5.4$ & 42 \\
\hline 48 & Annexin A4 & P09525 & $21(61)$ & $35,883 / 5.8$ & 56 \\
\hline 49 & Platelet-activating factor acetylhydrolase IB beta subunit & Q29459 & $5(18)$ & $25,569 / 5.6$ & 15 \\
\hline 50 & Prohibitin & P35232 & $10(30)$ & $29,804 / 5.6$ & 30 \\
\hline 51 & Peroxiredoxin 4 & Q13162 & $12(40)$ & $30,540 / 5.9$ & 45 \\
\hline 54 & Endoplasmic reticulum protein ERp29 precursor & P30040 & $8(30)$ & $28,994 / 6.8$ & 30 \\
\hline 55 & Antioxidant protein 2 & P30041 & $11(35)$ & $25,035 / 6.0$ & 48 \\
\hline 56 & Proteasome subunit alpha type 1 & $\mathrm{P} 25786$ & $11(45)$ & $29,556 / 6.1$ & 34 \\
\hline 57 & Adenosylhomocysteinase & P23526 & $15(51)$ & $47,717 / 5.9$ & 34 \\
\hline 58 & Tubulin beta- 5 chain & P05218 & $20(47)$ & $49,671 / 4.8$ & 39 \\
\hline 59 & T-complex protein 1 , beta subunit & P78371 & $20(52)$ & $57,489 / 6.0$ & 56 \\
\hline 60 & Ubiquinol-cytochrome $\mathrm{C}$ reductase complex core protein I & P31930 & $16(55)$ & $52,619 / 5.9$ & 30 \\
\hline 61 & RuvB-like 2 & Q9Y230 & $15(55)$ & $51,157 / 5.5$ & 34 \\
\hline 62 & Keratin, type II cytoskeletal 8 & P05787 & $16(61)$ & $53,675 / 5.5$ & 34 \\
\hline 63 & Protein disulfide isomerase A3 precursor & P30101 & $17(51)$ & $56,782.9 / 5.99$ & 32 \\
\hline 64 & Advillin (p92) & 075366 & $20(71)$ & $92,087 / 5.3$ & 26 \\
\hline 65 & Transitional endoplasmic reticulum ATPase & P55072 & $18(51)$ & $89,323 / 5.1$ & 20 \\
\hline 66 & HEAT SHOCK 70 KDA PROTEIN 4 & P34932 & $12(50)$ & $94,301 / 5.2$ & 20 \\
\hline 68 & Splicing factor 3 subunit 1 & Q15459 & $14(60)$ & $88,887 / 5.2$ & 17 \\
\hline 69 & HSPC108 & 6841440 & $8(42)$ & $37,145.7 / 5.83$ & 33 \\
\hline 70 & HSPC140 & 6841502 & $7(36)$ & $38,419 / 5.0$ & 28 \\
\hline 71 & SEC13-related protein & P55735 & $6(40)$ & $35,568.9 / 5.22$ & 27 \\
\hline 72 & $\mathrm{p} 47$ & 5531827 & $9(36)$ & $40,572 / 5.0$ & 26 \\
\hline 73 & p47 protein & 20149635 & 11 (37) & $40,573 / 5.0$ & 34 \\
\hline 74 & $26 \mathrm{~S}$ protease regulatory subunit $6 \mathrm{~A}$ & P17980 & $17(50)$ & $49,204.0 / 5.13$ & 30 \\
\hline 75 & p47 protein & 20149635 & $15(68)$ & $40,573 / 5.0$ & 41 \\
\hline 76 & Gamma enolase & P09104 & $13(48)$ & $47,137.8 / 4.91$ & 36 \\
\hline
\end{tabular}


Table 1. Continued

\begin{tabular}{|c|c|c|c|c|c|}
\hline $\begin{array}{l}\text { Spot } \\
\text { No. }\end{array}$ & Protein name & $\begin{array}{c}\text { Accession } \\
\text { No. }\end{array}$ & $\begin{array}{l}\text { Masses } \\
\text { matach }\end{array}$ & $\begin{array}{c}\mathrm{Mw} \\
(\mathrm{kDa}) / \mathrm{pI}\end{array}$ & $\begin{array}{c}\text { Seq. } \\
\text { coverage }\end{array}$ \\
\hline 77 & Histone acetyltransferase type B subunit 2 & Q16576 & $9(45)$ & $47,820.5 / 4.89$ & 20 \\
\hline 78 & Chromatin assembly factor 1 subunit $\mathrm{C}$ & Q09028 & $12(52)$ & $47,656.1 / 4.74$ & 25 \\
\hline 79 & Placental ribonuclease inhibitor & P13489 & $10(29)$ & $49,842.8 / 4.71$ & 36 \\
\hline 82 & Glycyl-tRNA synthetase & P41250 & $8(53)$ & $83,140.3 / 6.61$ & 13 \\
\hline 83 & T-complex protein 1 , alpha subunit & P17987 & $14(51)$ & $60,344.1 / 5.80$ & 28 \\
\hline 84 & Aldehyde dehydrogenase, mitochondrial precursor & P05091 & $10(37)$ & $56,382 / 6.6$ & 20 \\
\hline 85 & Heterogeneous nuclear ribonucleoprotein $\mathrm{H}$ & P31943 & $9(34)$ & $49,230 / 5.9$ & 25 \\
\hline 87 & Ezrin $(\mathrm{p} 81)$ & P15311 & $16(64)$ & $69,399 / 5.9$ & 22 \\
\hline 88 & T-complex protein 1, gamma subunit & P49368 & $16(57)$ & $60,403 / 6.1$ & 30 \\
\hline 90 & Heat shock-related $70 \mathrm{kDa}$ protein 2 & P54652 & $9(50)$ & $70,022 / 5.6$ & 19 \\
\hline 91 & Heterogeneous nuclear ribonucleoprotein $\mathrm{K}$ & Q07244 & $8(27)$ & $50,977 / 5.4$ & 18 \\
\hline 92 & Lamin B1 & P20700 & $18(62)$ & $66,409 / 5.1$ & 32 \\
\hline 93 & Lamin B1 & P20700 & $19(67)$ & $66,409 / 5.1$ & 35 \\
\hline 94 & Heterogeneous nuclear ribonucleoprotein $\mathrm{K}$ & Q07244 & $15(57)$ & $50,976.7 / 5.39$ & 31 \\
\hline 95 & $60 \mathrm{kDa}$ heat shock protein & P10809 & $11(44)$ & $61,055.2 / 5.70$ & 28 \\
\hline 96 & Serine/threonine protein phosphatase $2 \mathrm{~A}$ & P30153 & $18(54)$ & $65,092.9 / 4.97$ & 35 \\
\hline 97 & ATP synthase beta chain, mitochondrial precursor & P06576 & $24(51)$ & $56,560.4 / 5.26$ & 43 \\
\hline 98 & $26 \mathrm{~S}$ protease regulatory subunit $6 \mathrm{~B}$ & P43686 & $14(50)$ & $47,366.7 / 5.09$ & 36 \\
\hline 99 & Protein disulfide isomerase precursor & P07237 & $17(56)$ & $57,116.8 / 4.76$ & 32 \\
\hline 100 & Elongation factor 1-delta & P29692 & $10(47)$ & $31,122.1 / 4.90$ & 32 \\
\hline 101 & Thioredoxin-like protein & O43396 & $5(45)$ & $32,251.6 / 4.84$ & 22 \\
\hline 102 & Nucleoside diphosphate kinase A & P15531 & $6(40)$ & $17,148.9 / 5.83$ & 47 \\
\hline 103 & Proteasome activator complex subunit 1 & Q06323 & $14(51)$ & $28,723.3 / 5.78$ & 53 \\
\hline 104 & G-rich sequence factor-1 & Q12849 & $6(46)$ & $47,999.9 / 5.51$ & 15 \\
\hline 105 & Heterogeneous nuclear ribonucleoprotein $\mathrm{F}$ & P52597 & $9(52)$ & $45,672.3 / 5.38$ & 27 \\
\hline 110 & My027 protein & 12001996 & $10(52)$ & $33,233.1 / 5.40$ & 29 \\
\hline 111 & Microtubule-associated protein RP/EB family member 1 & Q15691 & $10(55)$ & $29,999 / 5.0$ & 42 \\
\hline 113 & Keratin, type I cytoskeletal 19 & P08727 & $13(56)$ & $44,106 / 5.0$ & 28 \\
\hline 116 & Branched-chain amino acid aminotransferase, cytosolic & P54687 & $9(47)$ & $42,806 / 5.2$ & 19 \\
\hline 117 & $53 \mathrm{kDa}$ BRG1-associated factor A & O96019 & $12(54)$ & $47,461 / 5.4$ & 25 \\
\hline 118 & Keratin, type I cytoskeletal 18 & P05783 & $19(50)$ & $48,058 / 5.3$ & 38 \\
\hline 119 & Activator of $90 \mathrm{kDa}$ heat shock protein ATPase homolog 1 & O95433 & $8(25)$ & $38,275 / 5.4$ & 23 \\
\hline 120 & Proteasome subunit beta type 4 precursor & $\mathrm{P} 28070$ & $6(31)$ & $29,192 / 5.7$ & 21 \\
\hline 121 & Transaldolase & P37837 & $13(76)$ & $37,540 / 6.4$ & 32 \\
\hline 123 & Septin 2 & Q15019 & $8(40)$ & $41,488 / 6.1$ & 23 \\
\hline 124 & Glutathione synthetase & P48637 & $10(40)$ & $52,385 / 5.7$ & 22 \\
\hline 127 & Heterogeneous nuclear ribonucleoprotein $\mathrm{K}$ & Q07244 & $5(22)$ & $50,977 / 5.4$ & 12 \\
\hline 128 & LaminB2 & Q03252 & $9(45)$ & $67,689 / 6.1$ & 16 \\
\hline 129 & Mitochondrial inner membrane protein & Q16891 & $10(40)$ & $83,679 / 6.1$ & 15 \\
\hline 130 & Mitochondrial inner membrane protein & Q16891 & 7 (46) & $83,679 / 6.1$ & 11 \\
\hline 132 & Elongation factor 1-delta & P29692 & $7(31)$ & $31,122 / 4.9$ & 33 \\
\hline 134 & Cytochrome b5 & P00167 & $5(38)$ & $15,199.0 / 4.88$ & 49 \\
\hline 136 & Spermidine synthase & P19623 & $7(41)$ & $33,825 / 5.3$ & 22 \\
\hline 137 & Alpha-soluble NSF attachment protein & P54920 & $9(45)$ & $33,247 / 5.2$ & 40 \\
\hline 138 & Heterogeneous nuclear ribonucleoprotein $\mathrm{K}$ & Q07244 & $6(27)$ & $50,977 / 5.4$ & 14 \\
\hline 139 & Glutaminase, kidney isoform, mitochondrial precursor & O94925 & $6(24)$ & $73,462 / 7.8$ & 10 \\
\hline 142 & Nicotinate-nucleotide pyrophosphorylase & Q15274 & $6(42)$ & $30,815.9 / 5.81$ & 23 \\
\hline 143 & Serine/threonine protein phosphatase PP1-beta catalytic subunit & P37140 & $9(37)$ & $37,187.2 / 5.84$ & 28 \\
\hline 145 & Transaldolase & P37837 & $8(36)$ & $37,540.5 / 6.36$ & 18 \\
\hline 146 & $60 \mathrm{~S}$ acidic ribosomal protein $\mathrm{P} 0$ & P05388 & $5(38)$ & $34,273.8 / 5.72$ & 16 \\
\hline 148 & $60 \mathrm{~S}$ acidic ribosomal protein $\mathrm{P} 0$ & P05388 & $6(35)$ & $34,273.8 / 5.72$ & 23 \\
\hline 149 & F-actin capping protein alpha- 2 subunit & P47755 & $5(22)$ & $32,949.4 / 5.57$ & 23 \\
\hline 150 & Guanine nucleotide-binding protein $\mathrm{G}(\mathrm{I}) / \mathrm{G}(\mathrm{S}) / \mathrm{G}(\mathrm{T})$ beta subunit 1 & P04901 & $5(33)$ & $37,377.3 / 5.60$ & 15 \\
\hline
\end{tabular}


폐암환자의 혈청에서 암 세포에 대한 자가 면역 반응을 유 발하는 종양항원을 프로티움 연구를 통하여 동정하고자 하 는 연구한 연구결과도 보고되고 있다 $(12,13)$. 본 연구에서 구축한 소세포 폐암에서의 단백질 지도는 이러한 연구의 상호 보완적인 기반자료가 될 수 있다. 암세포 이외에 혈 액, 침, 양수 등의 다양한 체액에 대한 분석도 시도되었고 (14 16), 항암약제내성, 세포사멸 등과 관련된 특이 항원도 동정되기 시작하였으며 이를 기반으로 한 암 세포생리 연 구를 통하여 진단 및 치료법 개발에 역할을 할 수 있을 것 으로 보인다 $(17,18)$.

한편 아직 개선해야 할 여러 기술적인 문제들도 남아있 다. 통상적으로 유핵세포에서 분리할 수 있는 총 단백질은 은 염색에서 $4,000 \sim 5,000$ 개의 스폿이 분리될 수 있으나 통 상은 그 절반에 그치고 있으며 비용해성 단백질 동정의 어 려움도 용해 buffer의 개량 등을 통하여 향후 개선해야 할 문제들이다. 조직 분석에서 여러 세포의 혼입에 의한 자료 의 일관성 부족 문제, 재현성 부족에 의한 연구 결과 편차의 문제 등도 해결해야 할 문제들이다. 이러한 난점의 개선 방 안의 하나로 각 시료 간 비교를 주로 하는 연구의 경우 연 구방법의 편차를 줄이기 위하여 각기 다른 fluorescent 색소 를 단백질에 붙여 2개 이상의 시료를 한번의 전기영동으로 분석하는 방법도 실용화되어 향후의 연구에서는 응용이 가 능하다(19). 본 연구에서는 1종의 암 세포주를 분석하였는 데 암 세포주의 특성상 배양 조건에 따라 상이한 단백질 발현양상이 나타날 수 있고 같은 폐암종이라할지라도 세포 아형에 따라 생물학적 양상이 상이함으로 본 연구 결과는 폐암세포에서의 단백질 발현 양상을 대표한다고 할 수는 없다. 따라서 이러한 다양한 조건에서의 단백질 발현 양상 을 연구하는 추가 연구가 따라야 할 것이다. 또한 체외 배양 된 세포주에서의 단백질 발현 양상이 생체조직에서의 발현 을 많은 부분 반영하지만 기원이 다른 여러 세포가 섞여있 는 생체조직에서 내에서는 발현 양상에 차이를 보일 수 있 으므로 환자의 조직을 대상으로 한 단백질 동정도 향후 연 구에서 이루어져야 할 부분으로 본 연구에서의 자료들은 이러한 연구 결과들과 상호보완적으로 해석하여야 할 것이다.

\section{결 론}

본 연구에서는 이차원 전기영동을 통한 단백질 분리 및 MALDI-TOF MS를 이용한 단백질 분석을 통하여 소세포폐 암세포주에서 발현되는 단백질들을 동정하여 단백질 표준 지도를 구축하였다. 본 연구에 이용된 이차원 전기영동 및 mass spectrometry에 의한 단백질 분석법을 이용한 프로티움 분석법은 암 세포에서 분리된 단백질들의 스크리닝을 위한
빠르고, 민감하며 신뢰성 있는 연구방법이다. 이렇게 얻어 진 자료는 향후 소세포 폐암의 병태 생리 연구 및 진단 치 료제 개발 등에 초석이 될 수 있을 것이다.

\section{REFERENCES}

1. Tyers M, Mann M. From genomics to proteomics. Nature 2003;422:193-197.

2. Ostergaard M, Rasmussen HH, Nielsen HV, Vorum H, Orntoft TF, Wolf H, Celis JE. Proteomic profiling of bladder squamous cell carcinoma: Identification of markers that define their degree of differentiation. Cancer Res 1997;57: 4111-4117.

3. Kim J, Kim SH, Lee SU, Ha GH, Kang DG, Ha NY, Cho HY, Kang SJ, Lee YJ, Hong SC, Ha WS, Bae JM, Lee CW, Kim JW. Proteome analysis of human liver tumor tissue by two-dimensional gel electrophoresis and matrix assisted laser desorption/ionization-mass spectrometry for identification of disease-related proteins. Electrophoresis 2002;23:4142-4156.

4. Ha GH, Lee SU, Kang DG, Ha NY, Kim SH, Bae JM, Kim JW, Lee CW. Proteome analysis of human stomach tissue: separation of soluble proteins by two-dimensional polyacrylamide gel electrophoresis and identification by mass spectrometry. Electrophoresis 2002;23:2513-2524.

5. Chen ST, Pan TL, Tsai YC, Huang CM. Proteomics reveals protein profile changes in doxorubicin-treated MCF-7 human breast cancer cells. Cancer Lett 2002;181:95-107.

6. Shin H, Ahn Y, Bae J, Shin M, Lee D, Lee C, Ohrr H, Ahn D, Ferlay J, Parkin DM, Oh D, Park J. Cancer incidence in Korea. Cancer Res Treat 2002;34:405-408.

7. Phizicky E, Bastiaens PI, Zhu H, Snyder M, Fields S. Protein analysis on a proteomic scale. Nature 2003;422:208-215.

8. Hanash S. Disease proteomics. Nature 2003;422:226-232.

9. Cellis JE. Proteomics: key technology in drug discovery. Drug Discov Today 1998;3:193-195.

10. Bergman A, Benjamin T, Alaiya A, Waltham M, Sagaguchi K, Lincer S, Bergman T, Auer G, Appella E, Wirth PJ, Jornvall $\mathrm{H}$. Identification of gel-seperated tumor marker proteins by mass spectrometry. Electrophoresis 2000;21:679-686.

11. Cellis JE, Rasmussen HH, Leffers H, Madsen P, Honore B, Gesser B, Vanderkerckhove J. Human cellular protein patterns and their link to genome DNA sequence data: usefulness of two dimensional gel electrophoresis aned microsequencing. FASEB J 1991;5:2200-2208.

12. Li C, Chen Z, Xiao Z, Wu X, Zhan X, Zhang X, Li M, Li J, Feng X, Liang S, Chen P, Xie JY. Comparative proteomics analysis of human lung squamous carcinoma. Biochem Biophys Res Commun 2003;309:253-260.

13. Brichory F, Beer D, Le Naour F, Giordano T, Hanash S. Proteomics-based identification of protein gene product 9.5 as a tumor antigen that induces a humoral immune response in lung cancer. Cancer Res 2001;61:7908-7912.

14. Beeley JA, Khoo KS. Salivary proteins in rheumatoid arthritis and Sjogren syndrome. Electrophoresis 1999;20:1652-1660.

15. Liberatori S, Bini L, De Felice C, Magi B, Marzocchi B, Frutiger S, Sanchez J, Wilkins MR, Hughes G, Hochstrasser DF, Bracci R, Pallini V. A two-dimensional protein map of human amniotic fluid at 17 weeks' gestation. Electrophoresis 1997; 18:2816-2822.

16. Bini L, Magi B, Marzocchi B, Cellesi C, Berti B, Rossolini A, Pallini V. Two-dimensional electrophoretic patterns of acutephase human serum proteins in the course of bacterial and viral diseases. Electrophoresis 1996;17:612-616. 
17. Jang JS, Cho H, Lee W, Lww CW, Park Y. Differential protein profile analysis of breast cancer cell line with drug resistance. Proc Am Asso Cancer Res 2003;44:962(abst 4839)

18. Brockstedt E, Rickers A, Kostka S, Laubersheimer A, Dorken B, Bommert K, Otto A. Identification of apoptosis-associated proteins in a human Burkitt lymphoma cell line. J Biol Chem
1998;273:28057-28064.

19. Kondo T, Seike M, Mori Y, Fujii K, Yamada T, Hirohashi S. Application of sensitive fluorescent dyes in linkage of laser microdissection and two-dimensional gel electrophoresis as a cancer proteomic study tool. Proteomics 2003;3:1758-1766. 